\title{
Gender Issues in the Ivory Tower of Brazilian IR
}

\author{
Mariana Pimenta Oliveira Baccarini* \\ Xaman Korai Minillo** \\ Elia Elisa Cia Alves***
}

\begin{abstract}
What is the status of women in the discipline of International Relations (IR) in Brazil? This study provides a pioneering map of gender issues in Brazilian IR, focusing on inequality, discrimination and harassment. It includes a literature review as well as the findings of two sets of research: the first a survey of personal and professional issues faced by academic staff in Brazilian IR, and the second a report on the staffing of IR and related departments at private and public academic institutions in Brazil. Our research shows that despite the specificities of the Brazilian higher education system, Brazilian IR academics conform to international trends in respect of gender issues, facing monetary and/or familial inequalities and gender discrimination in their careers. It also shows that $25 \%$ of female academics have experienced undesired sexual contact at least once, and that there is a gap between male and female understandings of what constitutes sexual harassment.
\end{abstract}

Keywords: gender inequality; gender discrimination; sexual harassment; Brazilian International Relations; academia; MulheRIs; empirical analysis; gender studies.

\section{Introduction}

In the 1960s and 1970s, feminists fought, inter alia, for gender equality in the workplace. This agenda remains highly relevant, and in 2016, during an International Relations seminar about undergraduate and post-graduate education held in Florianópolis, in the Brazilian state of Santa Catarina, some women affiliated with the Brazilian Association of International Relations $(\mathrm{ABRI})^{1}$ organised the first meeting of the MulheRIs, a feminist group which seeks to promote gender equality in the Brazilian IR community, by encouraging research connecting IR to gender issues, among other goals.

\footnotetext{
* Federal University of Paraíba (UFPB), João Pessoa-PB, Brazil; marianabaccarini@gmail.com. ORCID iD 0000-0001-5429-1286.

** Federal University of Paraíba (UFPB), João Pessoa-PB, Brazil; xamankorai@gmail.com. ORCID iD 00000003-4892-6905.

*** Federal University of Pernambuco (UFPE), Recife-PE, Brazil; eliacia@gmail.com. ORCID iD 0000-00020434-7656.
} 
In line with these efforts, ${ }^{2}$ this article presents pioneering data about the status of women in the academic IR community in Brazil. Although this study is one of many examining gender issues in academia, this is the first about this cohort. We will report on a literature review, the findings of some international (mostly Western) studies, as well as research focused on Brazilian academia.

We understand academics to be professionals who, sharing competencies and educational backgrounds, work at universities and in research institutions, are involved in student education, and are committed to this profession and the institutional background in which it takes place (Schwartzman and Balbachevsky 1993). In this context, we conducted a survey about gender issues among ABRI members, and researched the gender composition of IR and related departments at public and private universities. Given that discrimination and harassment can discourage students from pursuing an academic career, we also include some findings about this cohort.

The article is organised into five sections. Following this introduction, we provide a theoretical framework for discussing gender inequality, discrimination, and harassment in academia. Next, we set out our methodology, followed by the preliminary results of our research, and a discussion of the findings. We conclude by commenting further on the findings as well as on the themes that emerged from our research that could help to further promote feminist and gender studies in Brazilian IR.

\section{Literature review}

Feminism refers to a shared project of understanding and addressing the oppression of women. Although there are many feminist initiatives and perspectives, they are all aimed at providing women with the resources they need to able to take greater control of their lives (Harding 2016). Broadly, feminist initiatives in the realm of science can be understood as two parallel movements. The first examines the androcentric beliefs and practices that underpin the reproduction of gender-normative stereotypes, and the marginalisation of issues of concern to women. The second, more practical, movement interrogates academic institutions, their work practices and their traditions of discriminating against and harassing women, thereby affecting knowledge production and its contents, methods and assumptions (Crasnow et al 2015).

Feminist critiques of the scientific establishment target the gender bias that permeates institutions, and question the idea that they are meritocratic and gender-neutral. Studies of the persistence of gender inequalities in contemporary scientific practice and research by feminist historians of science widely show how women have been historically excluded from or considered unfit for scientific work (Crasnow et al 2015).

We hope that contributing to the reduction of gender discrimination in Brazilian IR will not only be positive in itself, but will also help to improve knowledge production. ${ }^{3}$ In this section, we will first deal with gender inequalities and discrimination, and then with gender harassment. In both instances, we will start by looking at trends in western higher education institutions (HEIs) in general, and then focus on Brazilian specificities. 


\section{Gender inequality and discrimination in academia}

It is widely believed that academia is largely gender-neutral; however, universities are no exemplars of workplace equity. They are gendered institutions, historically marked by the presence of men, and aligned with the unequal gendered division of labour in traditional heterosexual family settings. Although the proportion of female teachers at HEIs has increased (Moschkovich and Almeida 2015; Balbachevsky and Holzhacker 2015), the latest Higher Education Census (INEP 2017) shows that most Brazilian academics are males. ${ }^{4}$

Dubois-Shaik and Fusulier (2017) show that women in contemporary European academia are disadvantaged by vertical segregation because universities have still not addressed issues that undermine female advancement, such as personal circumstances, parenthood and family. Thus it is no coincidence that European female academics tend to have fewer children than their male counterparts (Dubois-Shaik and Fusulier 2017).

Brazilian society displays a similar gendered inequality in expectations of care-giving: women are held responsible for child care and housework, which can influence work relations at Brazilian universities in turn. We recognise the country's specificities, notably that many middle and upper-class women retain (mostly black) working-class women under exploitative conditions for housework and care-giving (Biroli 2010, 2015, 2016)..$^{5}$ Nevertheless, our data shows that male IR academics tend to have more children than their female counterparts - a clear indicator of inequality.

Rivera (2017) and others have identified and written about traditional sexist family designs that favour male careers over female ones. She concludes that hiring committees at R1 (highest research activities) universities in the USA privilege males or single women over married women, and that married men are better paid than their female counterparts. While, in Brazil, staff at public universities are appointed via tender processes, which are ostensibly gender-neutral, some women have reported a sense of being devalued in the course of these processes, with their gender identified as a constraining factor. One survey respondent reported that she was rejected for a particular public post despite superior qualifications, and was told that this was because the work environment was better suited to men, and it was 'not her turn.' Only men were appointed, although there was a gender balance among the candidates.

In a ground-breaking 1965 article titled 'Women in Science: Why So Few?' Alice Rossi questioned the poor representation of women in the hard sciences in the USA, and concluded that women seeking an academic career faced personal and domestic deprivation. Her research yielded some striking results, among them that $9 \%$ of natural scientists were women. Reasons included the influence of family and society, encouraging women from childhood onwards to cultivate characteristics that clashed with those needed for a scientific career, such as independence, persistence and social isolation; 2) prioritising the search for a well-placed husband; 3) the option to become secondary teachers instead of scientists; and 4) the abandonment of scientific careers to take care of the household and children.

More than five decades have passed, and much has changed, but some of Rossi's observations are still valid. Studies conducted in numerous countries show that the repre- 
sentation of women in academia has improved (Elsevier 2017), but that recruitment still displays a gender bias (Van den Brink and Benschop 2012), and that women still tend to receive lower salaries than men (Lee and Won 2014). ${ }^{6}$ Moreover, women are still underrepresented in senior faculty, which makes it more difficult for them to change institutional structures (Monroe et al 2008).

In 2008, Monroe et al (2008) interviewed 80 female professors at the University of California at Irvine (UCI) about conditions at the university. According to the authors, their careers were permeated by gender discrimination and devaluation in the following ways: 1) financially, through salary differences; 2) culturally, due to an 'old boy' network and an environment dominated by sexism and paternalism; 3) institutionally, due to administrative positions losing their status, power and authority when women took them over, and assuming supportive roles until they were reoccupied by men; 4) sexually, through harassment and open discrimination accompanied by the discouragement of official reports; 5) academically, by imposing more poorly valued administrative services on women and preventing them from focusing on their research; and 6) in family terms and socially, with gender role models making it virtually impossible for women to balance their family responsibilities and professional careers (Monroe et al 2008).

The respondents had adopted three political strategies for addressing these challenges: 1) formal legal and administrative mechanisms, which provided inefficient solutions with unclear benefits and high and real costs; 2) collective action, such as mentoring; and 3 ) individual coping, which led to women feeling that they needed to do more than men, and interpreting system failures as individual problems that were their own fault, sometimes leading to emotional exhaustion (Monroe et al 2008).

Recognition of the work of female academics in the USA is also harmed by gender discrimination and inequality. According to Macnell et al (2014), the gender bias can be observed even in performance evaluations. Their study found that students evaluated male and female instructors in different ways, with men receiving better scores in terms of criteria such as professionalism, availability, justice, respect and enthusiasm.

Fewer citations of articles and books written by women directly influence their career progression, resulting in delayed promotions and lower salaries. Several studies utilising different methods have shown that, in IR literature, articles written by women are quoted less often. Female authors are also mentioned less often in IR syllabi (Colgan 2017; Maliniak et al 2013; Mitchell et al 2013). ${ }^{7}$

Reconciling career and family is a Herculean task for women, who, regardless of their professions, tend to spend more time on house work and child care than men. This accumulation of functions leads to higher levels of work interference in family relationships and vice versa, and consequently stress. Type of work, flexibility and number of hours worked are relevant to this analysis, but authors also show that they have a differential impact on men and women (O'Laughlin and Bischoff 2005).

Tunguz (2016) argues that the regulation of external emotions regardless of internal feelings is easier for men than for women. Emotions needed in the academic environment, such as assertiveness, firmness and authority, are dominant in men and tenured academ- 
ics. Even after achieving tenure, women continue to find it more difficult to reconcile external and internal emotions, which leads to more stress.

People who have not experienced or witnessed gender discrimination tend to think that allegations of sexism are exaggerated, and some who have experienced instances of sexism believe they might have done something to cause such behaviour (Meyers 2013). ${ }^{8}$ Women are among those who resist the description of their work environments as 'chilly', that is, a pervasive institutional environment that hinders women's participation and is marked by systemic bias, hostility and sexism (Hall and Sander 1982). They also tend to regard their work environments as gender-neutral when they have evidence to the contrary (Briton 2017), minimising the importance of gender in workplace interactions and not identifying individual cases of sexism as part of a systemic institutional order (Prentice 2000: 196).

Hancock, Baum and Breuning (2013) conducted a global study about the differences in the productivity of women and men in IR, focusing on institutional environment, workload and family life. They found that the pipeline of advancement for women was 'leakier' than that of men. We hope this study will help to identify the conditions faced by women in Brazilian IR, considering the specificities of academic careers in this country.

In Brazil, the participation of women in research has increased in recent decades. According to $\mathrm{CNPq}$ (2013), by 2013 their numbers were equal to those of men, although they had not yet caught up in terms of research leadership. Nevertheless, as in the rest of the world, and despite the growing numbers of women students as well as lecturers, the higher the level (career, administrative positions and research grants), the lower the level of participation by women (Leta 2003; Grossi et al 2016).

Moschkovich and Almeida (2015) conducted a study at Universidade Estadual de Campinas (Unicamp), which, as a public university, provides a special opportunity for analysing possible gender discrimination faced by women, since it ostensibly experiences stability in admissions, and promotion decisions are controlled by the lecturers. According to the authors, there are two patterns of gender inequality at Unicamp: concentration in certain areas of knowledge, and fewer women in the highest positions, thus implying better wages and more prestige and power for men (Moschkovich and Almeida 2015; Velho and León 1998). Females remain a minority and are 'spread in a heterogeneous manner throughout the different areas of knowledge, faculties and institutes' (Moschkovich and Almeida 2015: 769), with fewer present in the exact sciences as well as in engineering. Regarding career progression, Unicamp's female academics are mostly at the lower levels. Women ascend differently in each academic area, college and institute. The authors also found that the degree of feminisation of a college does not have significant effects on women's ascension, and that women reach the highest levels at different speeds.

As noted in the literature on Europe and the USA, conflicts between careers and family obligations can hinder ascension and the acquisition of prestige, and also impact on academic production (Velho and León 1998). In seven units at Unicamp, women rose faster than men, in two, they rose at the same rate, and in 14, men rose faster than women. Women's chances of reaching higher positions at Unicamp were $12 \%$ lower than those 
of males. Moreover, they were concentrated in undergraduate co-ordination, with men taking over more prestigious positions, such as post-graduate co-ordination and the directorships of colleges and institutes. None of the twelve rectors at Unicamp was female (Moschkovich and Almeida 2015).

Brazilian Political Science and IR are still being studied. Mendes and Figueira (2017) present some interesting data about post-graduate courses. Although, between 2006 and 2016, women were responsible for $46.7 \%$ of defended master's theses, only $30.5 \%$ were supervised by women. Despite a substantial increase, only $36.9 \%$ of defended doctoral theses had been written by women, and just $23.4 \%$ of the total were supervised by women (Mendes and Figueira 2017). Of 592 teachers in post-graduate programmes, only 35\% (207) were women.

Finally, 50.8\% of the articles published in 15 journals in the period under review were written by women, perhaps because of 'blind' evaluations. However, Mendes and Figueira (2017) also noted a gender equilibrium among the authors of the most cited articles in each periodical, which cannot be attributed to ignorance of the authors' gender.

\section{Gender and sexual harassment in academia}

Sexual harassment can have various negative consequences, including depression, loss of appetite, nightmares or disturbed sleep, low self-esteem and feelings of fear. Among students, it can also lead to isolation, a loss of interest in scholarly activities, poorer school work and absenteeism (Gruber and Fineran 2007). Although sexual harassment is common among workers, especially women, it remains underdocumented. There is a general lack of understanding and awareness of what makes this so difficult to combat (Yee et al 2015), since many women who experience sexual harassment do not recognise this (Ellis, Barak and Pinto 1991; Magley et al 1999; Magley and Shupe 2005).

Sexual harassment can be understood as unwelcome gender and sex-related comments and behaviours, which can take the form of verbal (such as sexual comments or sexist jokes, taunts and rumours) or physical interaction, such as pulling their clothes or rubbing up against the person (Wolfe and Chiodo 2008). However, individual perceptions of such incidents are multiple and diverse; cultural contexts, personal experiences and exposure to information can shape what people understand as sexual harassment. To account for such differences, Yee et al (2015) stress the importance of considering any behaviours that violate the limits of personal boundaries as sexual harassment.

In the 1970s, Catharine MacKinnon (1979: 1) theorised sexual harassment as the unwanted imposition of sexual requirements in the context of a relationship of unequal power' and identified it as sexual discrimination deriving from power and masculinity. Following Uggen and Blackstone (2004) and Higa (2016), sexual harassment is the product of a performative gender system, in which gender and sexuality are imbued with power relations and where men wield sexual power over women to maintain their dominance and promote their masculinity.

According to Fitzgerald et al (1988), sexual harassment can take three forms: i) unwanted or offensive sexual attention such as inappropriate touching, romantic or sexual 
advances, or pressure for dates; ii) sexual coercion, which involves unwanted sexual pursuit connected to job-related threats or bribes to establish a sexual relationship; and iii) gender harassment, which does not involve sexual or romantic interest, but sexist hostility and degrading attitudes against women based on their gender.

Berdahl (2007: 425) defines gender harassment as 'a form of hostile environment harassment that appears to be motivated by hostility toward individuals who violate gender ideals.' Dresden et al (2017) identify it as actions such as derogatory remarks or comments about women being unsuitable for management, sexist jokes and coarse behaviour, which are frequently seen as less serious than other forms of harassment and, although common, are less likely to be identified as sexual harassment (Leskinen et al 2011; Fitzgerald and Ormerod 1991). Even though gender harassment is not directly related to sexual attention or coercion, this form of sexism can engender anger, anxiety and depression in its victims, as well as the perception that they need to overperform to be accepted and achieve recognition.

While it is widely understood that women can be sexually harassed by a superior or a person in a position of power, such attitudes and behaviours can also come from subordinates, constituting contra power sexual harassment (Benson 1984: 517). Highlighting the role of power and gender in these dynamics, this form of harassment can be used by men as an equaliser against women in power positions, because they are perceived as challenging their subordinate position in the gender system (McLaughlin et al 2012). It can occur in the academic context, and often goes institutionally unnoticed, with female faculty being targeted by male students with sexist comments, verbal sexual advances and propositions, physical advances and sexual bribery (Mohipp and Senn 2008).

The perceived causes of sexual harassment include numerical or normative male dominance in work environments, where such behaviour is used as a tool to maintain status differences between genders (Dresden et al 2017:3). While numerical male dominance refers to the prevalence of men within an institution's sex ratio, which is characteristic of STEM (science, technology, engineering and mathematics) academic fields, normative male dominance refers to environments marked by a culture of manhood. In a heterosexualised, racialised and classed gender order, sexual harassment is sometimes considered as a legitimate means for men to express their 'hegemonic masculinity' (Robinson 2005; Fukuda 2012). Given the socially constructed nature of the gender system, and the different prescriptions of sexuality for men and women, they are likely to have different perceptions of sexual harassment, and men can treat discussions of sexual harassment with patronising scepticism (Uggen and Blackstone 2004). This is acknowledged in the analysis of our findings and sheds light on the different perceptions men and women have of sexual harassment, which point to the urgent need to recognise it as gender violence and for action to be taken against it.

\section{Methodology}

Our research was conducted in two ways. First, in June and July 2017, we conducted a survey about personal and professional gender relations among faculty involved in Brazilian 
IR higher education, or academic staff. The questions were based on the CSW/WCIS 2015 Survey of Women in the Profession of International Studies (Hudson et al 2016), ${ }^{9}$ and adapted to the Brazilian context. The survey was developed at the request of MulheRIs and conducted online, with support from ABRI and MulheRIs. Second, in the second semester of 2017, we asked IR and related departments at 25 public and 62 private universities to provide us with information about their faculty composition. ${ }^{10}$ By December 2017, we had received replies from 29, most of them public HEIs (19).

Political scientists commonly use surveys to identify opinions, attitudes, values and perceptions. There are several types of surveys, usually classified as exploratory, descriptive or explicative research (Paranhos et al 2013). Our research could be classified as descriptive, since this is a first attempt to shed light on the status of women in Brazilian IR.

The authors acknowledge the limitations of the data, notably the fact that there may be a sample selection bias, including a self-selection bias. Our survey sample was not random, as only people interested in sharing their experiences responded to invitations to participate in the survey, which were issued by email. ${ }^{11}$ Another issue that emerged in the course of the data analysis was the specific structure of Brazilian universities, which impeded comparisons with other countries. Nevertheless, as a first effort, we believe our study is enlightening.

Regarding inequality, we focused on faculty, or academic staff. Regarding discrimination and sexual harassment, we included all respondents who were members of ABRI. We included male respondents in the survey in order to determine inequalities and the occurrence of sexual harassment and the abuse of women. However, since fewer men responded, this can affect the comparisons. Generational issues were not considered, but we recognise that this is a relevant variable to be explored in future research.

Besides multiple-choice questions, the survey also contained open-ended ones. Some of the responses are reported below as illustrative comments that are not systematically analysed, but convey the voices of respondents, and illuminate the issues in question.

\section{Results}

\section{Response rate and demographics}

The first issues examined are the response rate and degree of representativeness of the survey sample. ${ }^{12}$ With 376 responses received from 1118 ABRI members, the response rate of $33.57 \%$ can be regarded as good, given that a $5 \%$ rate is considered typical for such surveys (Hudson et al 2016). However, we received some unbalanced results due to the massive collaboration of women compared to low levels of male participation. As regards representativeness, we would have liked to compare our sample to ABRI's membership as well as other information about IR departments at Brazilian universities, across several demographic characteristics. However, no data is available about the age and race/ethnicity of ABRI's members. Therefore, we restricted the examination of representativeness to gender and rank. 
Table 1: Survey response rates by gender

\begin{tabular}{lrrrc}
\hline & \multicolumn{1}{c}{ Female } & \multicolumn{1}{c}{ Male } & Other & Total \\
\hline ABRI associates & 511 & 607 & & 1118 \\
\hline Survey respondents & 256 & 118 & 2 & 376 \\
\hline Compliance rate & $50.10 \%$ & $19.44 \%$ & & $33.63 \%$ \\
\hline
\end{tabular}

Source: created by the authors.

\section{Gender}

We received 376 valid survey responses - $256(68.09 \%)$ from females, 118 (31.38\%) from males, and two $(0.53 \%)$ from individuals who did not place themselves in either of these gender categories. We developed two hypotheses about the low compliance rate among men. The first was that men were apathetic about the issue at hand, and the second that they might have misunderstood the invitations to participate in the survey. Because the survey was presented as related to gender relations in academia, some men might have equated gender issues with women's issues, and thought that only women should respond. ${ }^{13}$ Nevertheless, since $50.10 \%$ of ABRI's female members responded, we can draw important inferences about the status of women in Brazilian IR. When we analyse the ratio of women in both samples, we note that female participation in ABRI is $45.71 \%$ of the total (511 out of 1118 members). Therefore, females are substantially overrepresented among the respondents.

\section{Rank}

The survey was also not entirely representative of ABRI membership in terms of rank. Whereas ABRI has three types of members, namely full members, student members and professional members, ${ }^{14}$ the survey records more specific positions.

Figure 1 shows that female faculty members are strongly represented in the survey $(86 \%)$, confirming their interest in the issue under study. Female students and professionals are also strongly represented (more than $40 \%$ ). For men, the figures are more than $30 \%$ of male faculty members, and about $15 \%$ of male students and professionals. This indicates that our results in respect of male academic staff are consistent.

\section{Partners and children}

We asked respondents whether they were 'partnered' - in other words, whether they were married or living with a partner. The results were roughly similar, with $38 \%$ of women and $46 \%$ of men declaring that they were living with someone. In order to investigate the difficulties mentioned in the literature of combining an academic career with family responsibilities, and the impacts of this on women and men, we filtered the responses, 
retaining only those of academics. Figure 2 shows that $55 \%$ of women and $66 \%$ of male academics were partnered.

Figure 1: ABRI members and survey respondents by position and gender

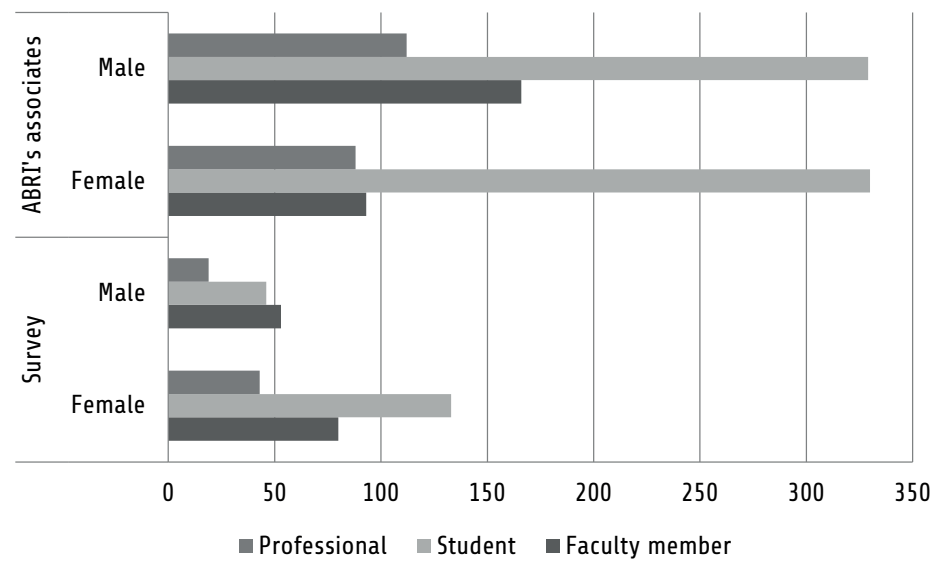

Source: created by the authors.

Figure 2: Relationship status of academic respondents by gender

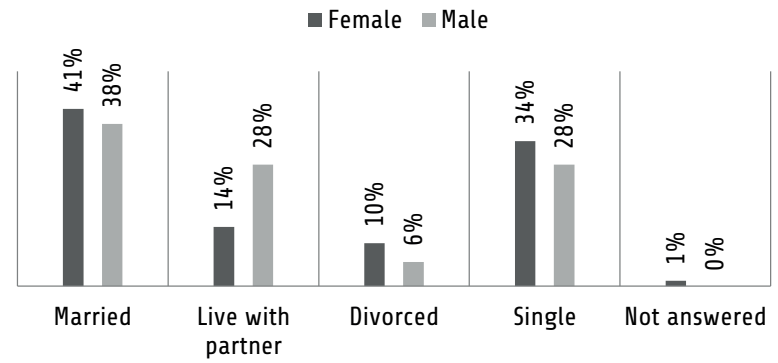

Source: created by the authors.

As regards clashing professional interests, $13.7 \%$ of female respondents reported that this had a negative impact on their relationships, compared with $7.6 \%$ of male respondents. Most respondents reported achieving a compromise or coming to a joint decision.

Participants were also asked about their offspring. The results in Figure 3 reinforce the literature about how academic life may limit the number of children women have or that they postpone having them. Considering only academics, male respondents were substantially more likely to have children than female respondents ( $46 \%$ of men and 35\% of females). Furthermore, $26 \%$ of women, against $19 \%$ of men, agreed with the statement that academic life influences the number of children they have (Figure 4). 
Figure 3: Clash of professional interests among faculty members by gender

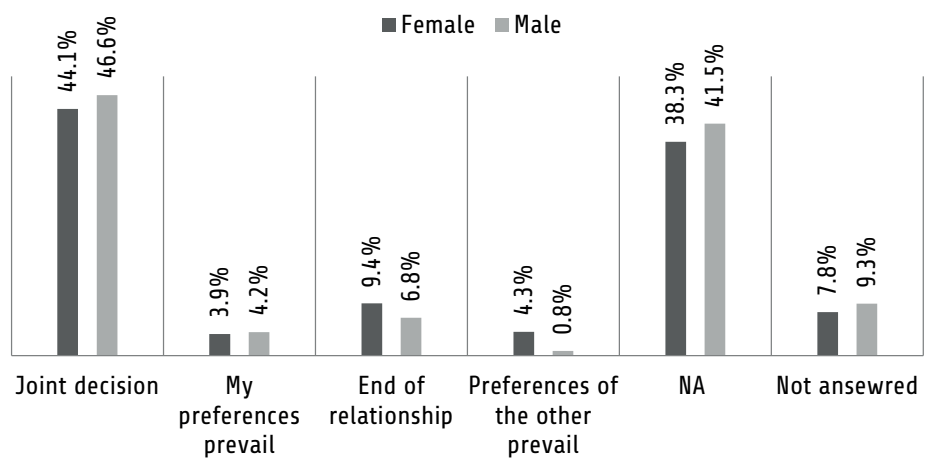

Source: created by the authors.

Figure 4: Number of children among faculty members by gender

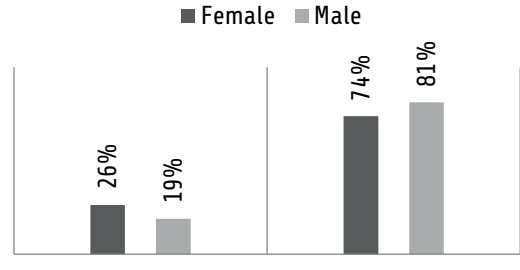

Yes

No

Source: created by the authors.

Figure 5: Academic life influencing the number of children among faculty members by gender

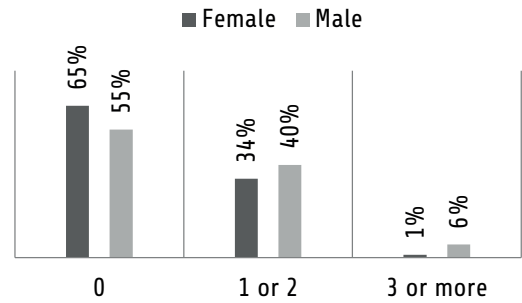

Source: created by the authors. 
Two respondents appended comments that illustrated how pregnancy could affect women's careers:

I was ordered to produce during my maternity leave; I was told that I was trying to cheat the university because I got pregnant.

Motherhood is always an issue, especially for women who are teachers in private institutions.

\section{The academic context and environment}

\section{Types of Institution}

Adjusted responses showed that most male and female respondents worked in public institutions.

Figure 6: Type of institution among academic professionals by gender

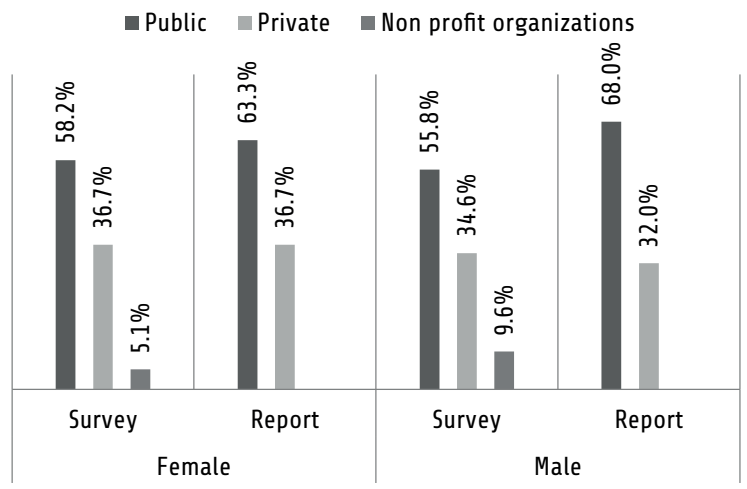

Source: created by the authors.

\section{Female faculty members}

Regarding female participation in faculty, we gathered information from the survey as well as the report. Table 2 presents information from the report. On average, male participation in IR and related departments was almost twice higher than those of females. One HEI reported a department staffed only by women, but this only comprised five academics. The most alarming features are the negative outliers (institutions with very few female professors). 
Table 2: Male and female representation in Brazilian IR departments

\begin{tabular}{|c|c|c|c|}
\hline Institution & Female & Male & Total \\
\hline UNIVERSIDADE FEDERAL FLUMINENSE & 0 & 16 & 16 \\
\hline UNIVERSIDADE FEDERAL DE GOIAS & 1 & 20 & 21 \\
\hline CENTRO UNIVERSITÁRIO SENAC SP & 2 & 11 & 13 \\
\hline UNIVERSIDADE FEDERAL DO RIO GRANDE & 2 & 5 & 7 \\
\hline UNIVERSIDADE FEDERAL DE GRANDES DOURADOS & 2 & 9 & 11 \\
\hline UNIVERSIDADE FEDERAL DE SERGIPE & 3 & 5 & 8 \\
\hline UNIVERSIDADE FEDERAL DE PELOTAS & 3 & 6 & 9 \\
\hline UNIVERSIDADE DO SAGRADO CORAÇÃO & 4 & 4 & 8 \\
\hline UNIVERSIDADE ESTADUAL DO RIO DE JANEIRO & 4 & 6 & 10 \\
\hline UNIVERSIDADE FEDERAL DE RORAIMA & 4 & 6 & 10 \\
\hline UNIVERSIDADE FEDERAL DO TOCANTINS & 4 & 8 & 12 \\
\hline UNIVALI(CAMBORIU) & 5 & 0 & 5 \\
\hline CENTRO UNIVERSITÁRIO BELAS ARTES DE SÃO PAULO & 5 & 11 & 16 \\
\hline UNICURITIBA & 5 & 15 & 20 \\
\hline UNIVERSIDADE ESTADUAL PAULISTA JULIO DE MESQUITA FILHO & 5 & 8 & 13 \\
\hline UNIVERSIDADE FEDERAL DA PARAÍBA & 5 & 10 & 15 \\
\hline CENTRO UNIVERSITÁRIO DE BELO HORIZONTE & 6 & 5 & 11 \\
\hline UNIVERSIDADE FEDERAL DE UBERLÂNDIA & 6 & 17 & 23 \\
\hline UNAERP - CAMPUS RIBEIRAO PRETO & 7 & 9 & 16 \\
\hline PUC GOIAS & 7 & 13 & 20 \\
\hline UNIVERSIDADE FEDERAL DA INTEGRAÇÃO LATINO AMERICANA & 7 & 11 & 18 \\
\hline UNIVERSIDADE DE BRASILIA & 7 & 14 & 21 \\
\hline UNIVALI (ITAJAI) & 8 & 19 & 27 \\
\hline UNIVERSIDADE FEDERAL DO AMAPA & 8 & 3 & 11 \\
\hline UNIVERSIDADE FEDERAL DE SÃO PAULO & 8 & 7 & 15 \\
\hline UNIVERSIDADE FEDERAL DO ABC & 8 & 22 & 30 \\
\hline PUC RIO & 9 & 9 & 18 \\
\hline UNIVERSIDADE FEDERAL DE SANTA CATARINA & 10 & 15 & 25 \\
\hline UNIVERSIDADE FEDERAL RURAL DO RIO DE JANEIRO & 13 & 16 & 29 \\
\hline Average & 5,4 & 10,3 & 15,8 \\
\hline Total & 158 & 300 & 458 \\
\hline
\end{tabular}

Source: created by the authors. 
The survey corroborated the results from the report, with 101 (63\%) of respondents declaring that female representation in IR departments was lower than $40 \%$ (see Figure 7).

Figure 7: Representation of female teachers in Brazilian IR faculties

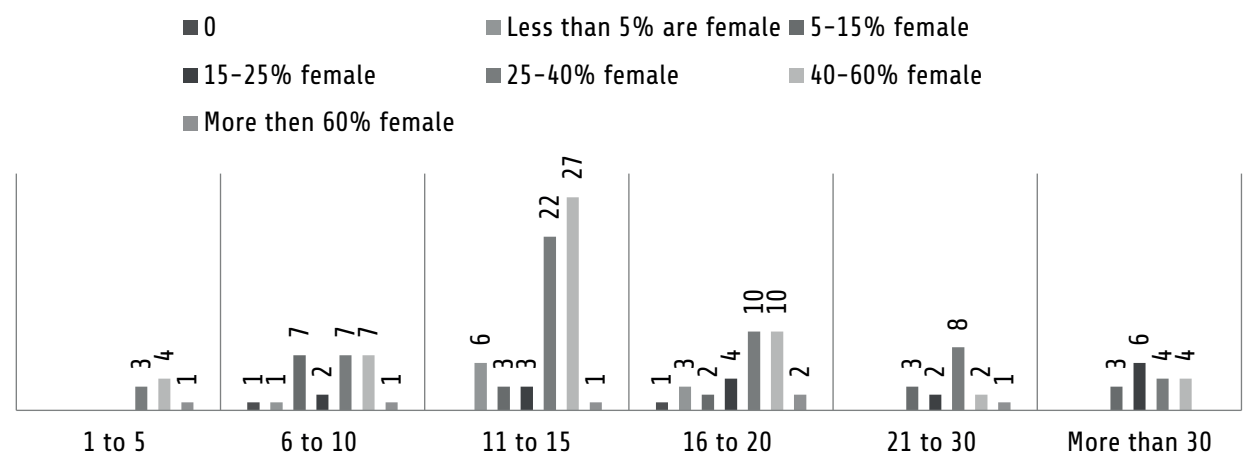

Source: created by the authors.

\section{Employment}

When asked whether they considered themselves underemployed, with lesser positions and less pay than they believed they should have, 55\% of women answered yes, against $48 \%$ of men. Some $41 \%$ of women and $29 \%$ of men said their careers were constrained by their partners. Academic staff were asked about ways in which their careers were constrained by their partners. In all but one category, more women were constrained by their partners than men (Figure 8).

Figure 8: Career choices constrained by partner, academic staff only

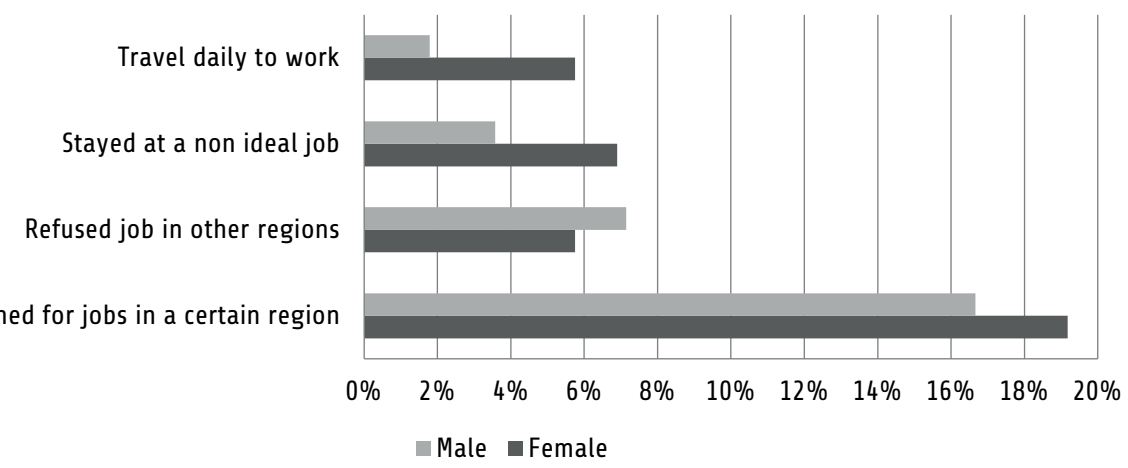

Source: created by the authors. 


\section{Financial gap}

Following Monroe et al (2008), we set out to examine gender differences in salaries as well. Figure 9 presents a relatively balanced picture in respect of the salaries of academic staff only, although no female professor earned more than $\mathrm{R} \$ 20,000$ a month, while $3.6 \%$ of male professors did. The relatively small salary gap can be attributed to the fact that most professors who responded to the survey worked at public institutions. This is corroborated by Figure 10, which reveals a bigger pay gap among academic staff at private institutions only. ${ }^{15}$

Figure 9: Salary differences, academic staff only

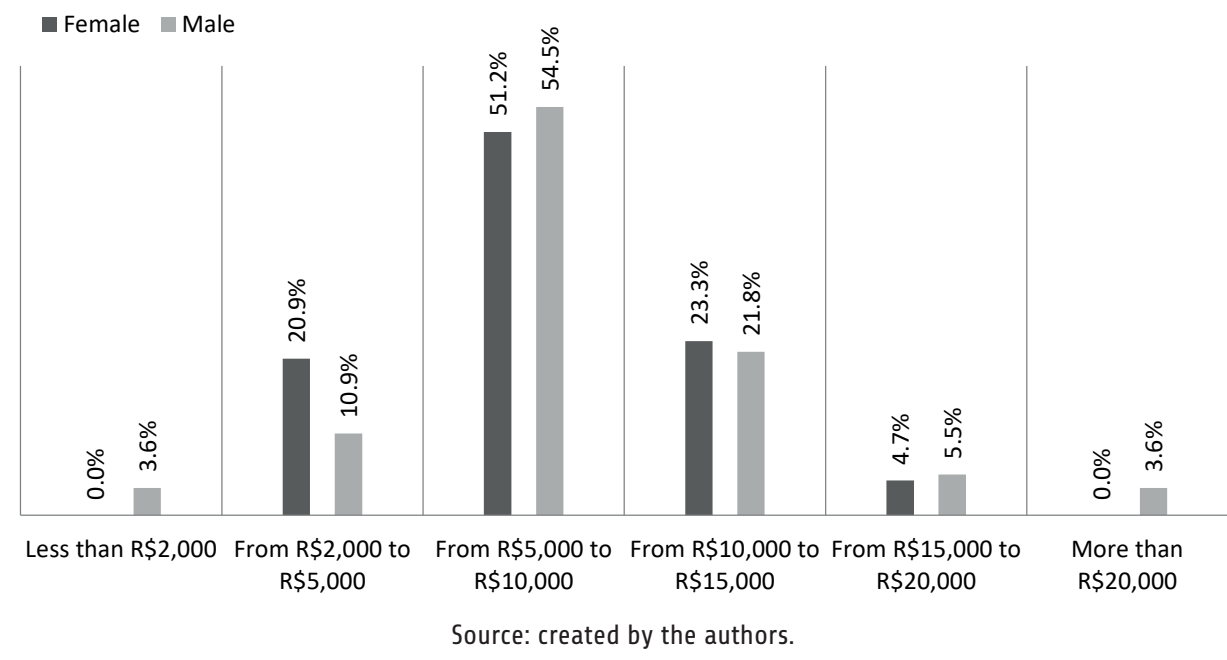

Figure 10: Salary differences, academic staff at private institutions

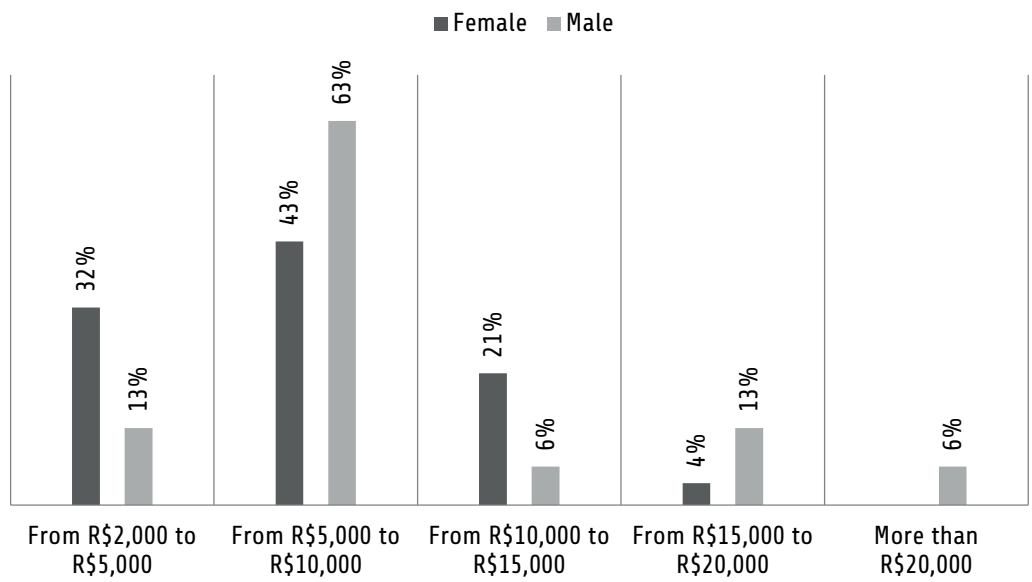

Source: created by the authors. 
We sought to illuminate another discrepancy pointed out by Monroe et al (2008), namely those among people in administrative positions. The results are presented in Table 3.

Table 3: Occupation of administrative positions, academic staff only

\begin{tabular}{lcc}
\hline Position & Male (Total 56) & Female (Total 87) \\
\hline Rector & 0 & 0 \\
\hline Vice-rector & $3(5.3 \%)$ & 0 \\
\hline Centre director & $1(1.7 \%)$ & $3(3.4 \%)$ \\
\hline Centre vice-director & 0 & 0 \\
\hline Head Department & $8(14.2 \%)$ & $6(6.8 \%)$ \\
\hline Vice-head department & 1 & $11(12.6 \%)$ \\
\hline Graduate coordinator & $7(12.5 \%)$ & $12(13.8 \%)$ \\
\hline Graduate vice-coordinator & $4(7.1 \%)$ & $28(32 \%)$ \\
\hline Undergrad coordinator & $15(27 \%)$ & $12(13.7 \%)$ \\
\hline Undergrad vice-coordinator & $8(14.2 \%)$ & \\
\hline
\end{tabular}

Source: created by the authors.

We were unable to draw significant and consistent conclusions, because each institution is structured differently, and in some organisations it seemed easier to for women to rise to higher positions than others. In this respect, one respondent noted:

Working in the academic area requires a redoubled effort from women, because IR is still dominated by men.

\section{Workload and production}

Regarding the workload of academics, higher education in Brazil is structured around three main functions: research, teaching and community engagement. Our survey did not ask about involvement in community engagement projects, which may have misrepresented the activities of female academics, and should be addressed in future studies. More male than female professors were supervising more than five students each.

Also, $45 \%$ of men against $40 \%$ of women were teaching three or more disciplines, or courses, at the time of the survey.

As regards publications, the gap between male and female academic staff appeared to be wider. We analysed this in terms of four dimensions. First, 23\% of women, compared to $32.2 \%$ of men, had authored or co-authored two or more books. Second, $26 \%$ of women against $30 \%$ of men had edited or co-edited at least one book. Third, $52 \%$ of women against $56 \%$ of men had had three or more chapters published in books. Lastly, $66 \%$ of 
women against $79 \%$ of men had had more than three articles published by journals indexed in Brazil's Qualis-Capes system.

Figure 11: Number of supervised students by gender

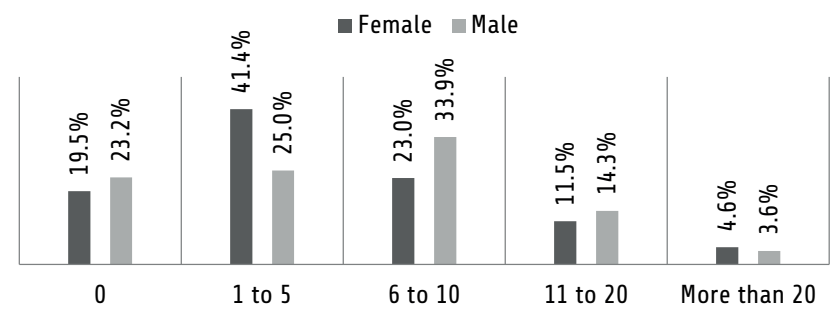

Source: created by the authors.

Figure 12: Number of disciplines taught by gender

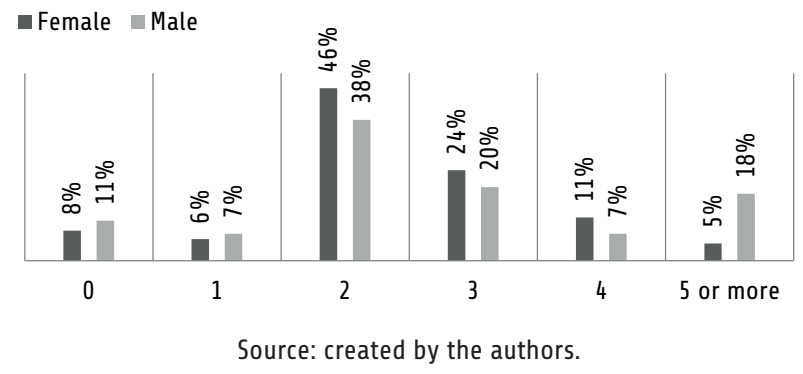

Figure 13: Number of books authored/co-authored by gender

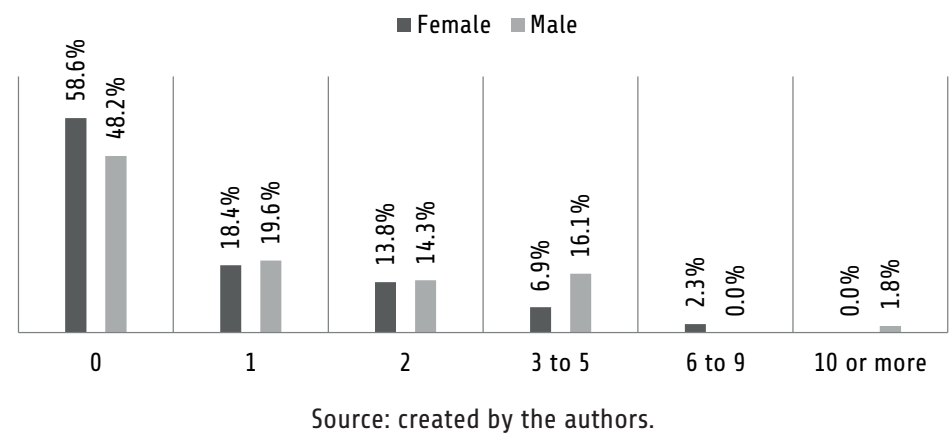


Figure 14: Number of books edited/coedited by gender

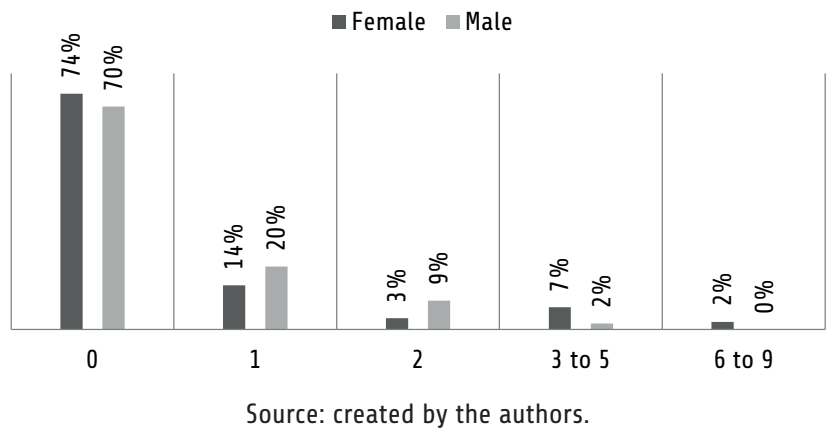

Figure 15: Number of book chapters published by gender

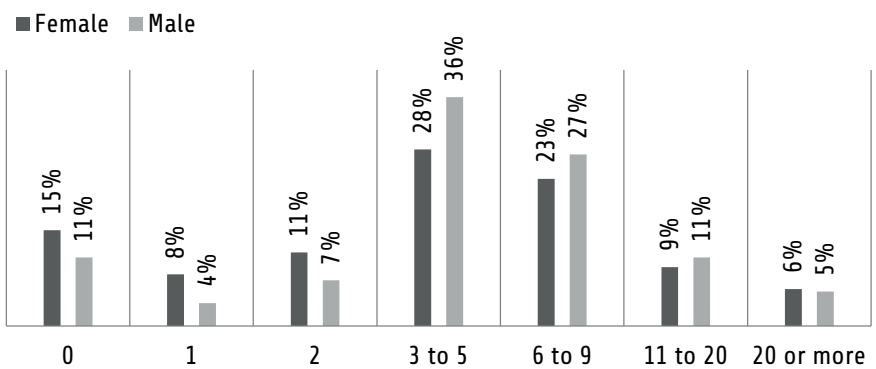

Source: created by the authors.

Figure 16: Number of articles in journals indexed by Qualis by gender

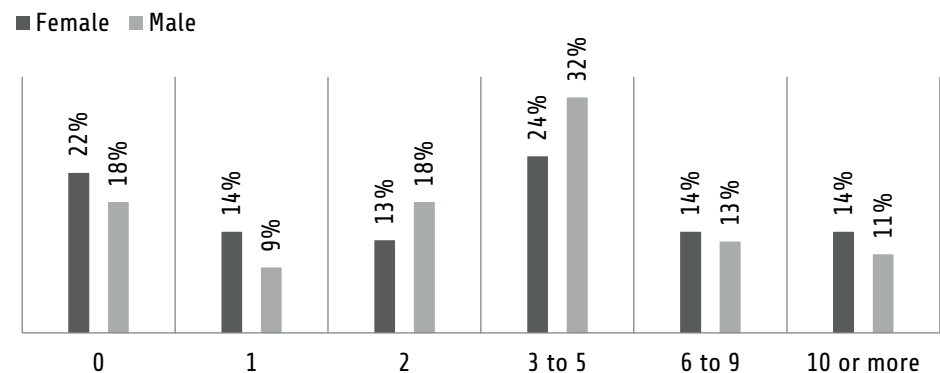

Source: created by the authors. 


\section{Discrimination and sexism}

More than $60 \%$ of women said they had experienced gender discrimination in the academic environment. Figure 17 presents the different kinds of discrimination experienced by women professors. The results from students and staff were similar.

We performed the Chi-squared test to establish whether the differences between female and male respondents in respect of discrimination due to undertaking gender and feminist studies were statistically significant. The result was $\chi^{2}=47.27$ (p-value $\left.=0.00\right)$, indicating that being female correlates with a greater incidence of discrimination based on gender, as well as feminist research. ${ }^{16}$ The following comments by two female respondents shed light on this issue:

My work has been disqualified countless times for having as a subject the participation of women in centres of power. I heard commentators who tried to delegitimize the importance of gender studies. The departments are still very refractory to the subject, lacking institutionalization, and the higher quality journals seem impenetrable to studies outside mainstream IR.

Despite coming from a background in IR, I am currently part of a sociology department specialized in gender studies [...] this change in my research area has to do with an experience of sexism in IR departments.

Figure 17: Discrimination experienced in the academic environment by academic staff only

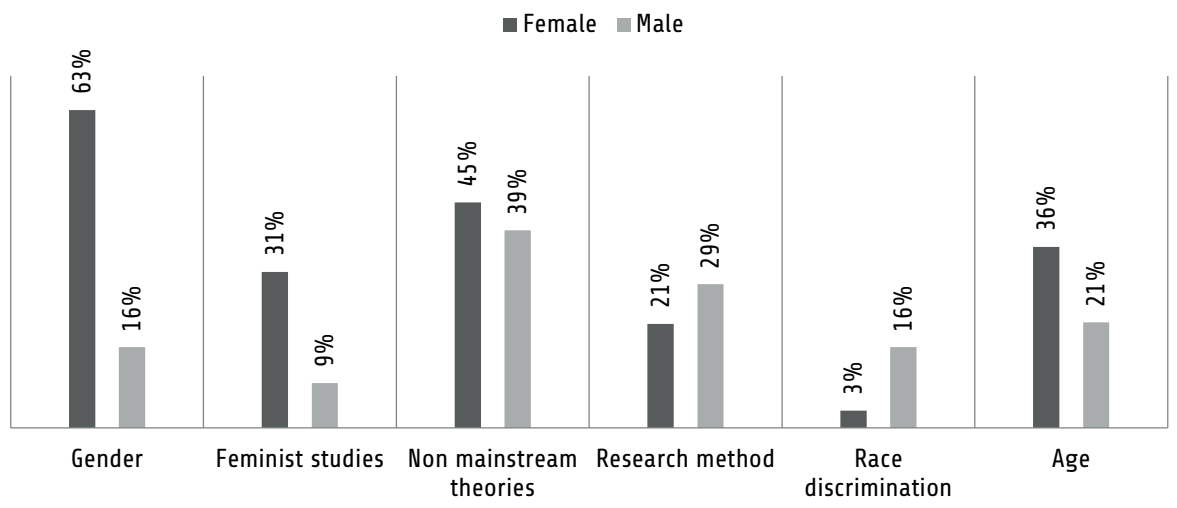

Source: created by the authors.

Some respondents disagreed, as the comment below illustrates. This comment by a male respondent reinforces our findings, and highlights the degree to which men and 
women may harbour different perceptions of discrimination, and the importance of discussing this issue.

Gender discrimination is not a problem in IR. Discrimination occurs due to the difficulty of poor people, or of smaller centres having access to the course.

Divergent perceptions also emerge from Figure 18, which shows that, in general, more men than women believed that their departments recognised gender issues, thereby signalling that they were more prone to the status quo. Only $17 \%$ of women entirely agreed that their departments recognised the importance of gender issues. The following comment points towards the relevance of other gender issues which were not addressed in this course of our research:

I'm a department director, and my male colleagues are not indifferent to the fact that I am married to another woman. [...] Beyond sexism, I believe that homosexuals are subtly restrained in their work environment.

When asked about their personal understanding of sexist behaviour, almost $90 \%$ of respondents agreed on the nature of inappropriate behaviour in the academic environment, as shown in Table 4.

Figure 18: Departmental recognition of gender issues by gender

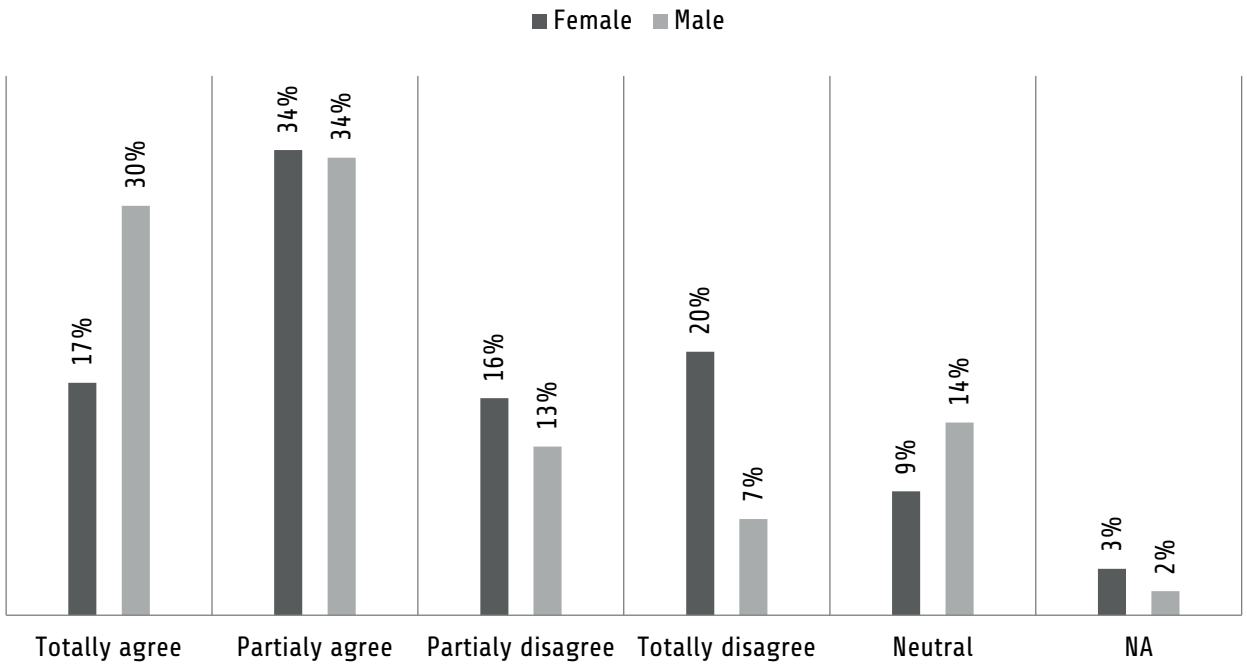

Source: created by the authors. 
Table 4: Personal understanding of sexist behaviour in the academic environment

\begin{tabular}{lcc}
\hline Behaviour & & Percentage \\
\hline \multirow{2}{*}{ Sexist language or humour } & Yes & $87.1 \%$ \\
\hline \multirow{2}{*}{ Not taking women seriously } & Sometimes & $9.65 \%$ \\
\hline \multirow{2}{*}{ Devaluation of women's professional activities } & Yes & $91.4 \%$ \\
\cline { 2 - 3 } & Sometimes & $6.17 \%$ \\
\hline \multirow{2}{*}{ Devaluation of academic work on women } & Yes & $93.8 \%$ \\
\cline { 2 - 3 } & Sometimes & $3.5 \%$ \\
\cline { 2 - 3 } & \multicolumn{2}{c}{ Yes } \\
\hline
\end{tabular}

Source: created by the authors.

We also explored the personal experiences of female academics who had suffered or witnessed instances of sexism, thus revealing important aspects of female experiences in Brazilian IR academia. About $66 \%$ of women respondents reported that they had occasionally or frequently experienced sexist jokes, or incidences of women not being taken seriously because of their gender.

Table 5: Female academics witnessing or experiencing sexism in IR academia

\begin{tabular}{lccccc}
\hline & $\begin{array}{c}\text { Never } \\
\text { experienced }\end{array}$ & $\begin{array}{c}\text { Only } \\
\text { witnessed }\end{array}$ & $\begin{array}{c}\text { Experienced } \\
\text { once }\end{array}$ & $\begin{array}{c}\text { Experienced } \\
\text { occasionally }\end{array}$ & $\begin{array}{c}\text { Experienced } \\
\text { frequently }\end{array}$ \\
\hline Jokes or sexist language & $6 \%$ & $17 \%$ & $7 \%$ & $37 \%$ & $30 \%$ \\
\hline $\begin{array}{l}\text { Women not being taken } \\
\text { seriously }\end{array}$ & $14 \%$ & $18 \%$ & $3 \%$ & $32 \%$ & $33 \%$ \\
\hline $\begin{array}{l}\text { Devaluation of professional } \\
\text { activities of women }\end{array}$ & $26 \%$ & $19 \%$ & $5 \%$ & $25 \%$ & $20 \%$ \\
\hline $\begin{array}{l}\text { Different standards for } \\
\text { defining departmental } \\
\begin{array}{l}\text { agendas and duties betwe- } \\
\text { en men and women }\end{array}\end{array}$ & $37 \%$ & $13 \%$ & $2 \%$ & $16 \%$ & $16 \%$ \\
\hline
\end{tabular}

Source: created by the authors.

Brazilian IR academia is still growing and faces many challenges. When an academic declares that being respected is still a matter of luck or privilege and not a right, it shows that much progress remains to be made. Nevertheless, the following statements reflect more positive perceptions of the academic environment:

I believe my experience has been unusually positive. I have been in a position to hear and observe sexism in the workplace, but I have been lucky to rarely experience it and to be in an extremely egalitarian institution. But I know that reality is an exception. 
I believe I have the privilege of being in an egalitarian environment. In this way, although I have already witnessed and experienced sexism in my life, I do not feel like a victim of this process in my current work environment.

I have never suffered gender discrimination at work; I have already led a group of men, in general much older, and everyone treated me with due respect.

\section{Sexual harassment}

This section contains perhaps the most distressing results of the survey. Participants were asked to indicate whether or not they regarded certain behaviours as instances of sexual harassment.

Table 6: Perceptions of behaviours as instances of sexual harassment

\begin{tabular}{|c|c|c|c|c|c|}
\hline \multirow{2}{*}{ Behaviour } & \multirow{2}{*}{ Gender } & \multicolumn{4}{|c|}{ Answer } \\
\hline & & Yes & Sometimes & No & I don't know \\
\hline \multirow{2}{*}{ Excessive eye contact } & Female & $53 \%$ & $35 \%$ & $8 \%$ & $4 \%$ \\
\hline & Male & $34 \%$ & $42 \%$ & $17 \%$ & $7 \%$ \\
\hline \multirow{2}{*}{$\begin{array}{l}\text { Comments on personal } \\
\text { appearance, clothing } \\
\text { and body }\end{array}$} & Female & $59 \%$ & $37 \%$ & $2 \%$ & $2 \%$ \\
\hline & Male & $41 \%$ & $45 \%$ & $9 \%$ & $5 \%$ \\
\hline \multirow{2}{*}{$\begin{array}{l}\text { Subtle pressure for } \\
\text { sexual activity }\end{array}$} & Female & $89 \%$ & $7 \%$ & $2 \%$ & $2 \%$ \\
\hline & Male & $79 \%$ & $9 \%$ & $6 \%$ & $6 \%$ \\
\hline \multirow{2}{*}{$\begin{array}{l}\text { Unwanted physical } \\
\text { contact done inten- } \\
\text { tionally }\end{array}$} & Female & $93 \%$ & $3 \%$ & $4 \%$ & $1 \%$ \\
\hline & Male & $85 \%$ & $4 \%$ & $6 \%$ & $5 \%$ \\
\hline
\end{tabular}

Source: created by the authors.

This is a relevant and complex issue, because, as shown by the results (which confirm the literature on this subject), people's perceptions of sexual harassment are fluid and are influenced by factors such as cultural contexts, personal experiences, access to information and gender. These factors make it more difficult to recognise and combat these forms of behaviour.

The following statements illustrate this:

In my view, mere flirtation, the xaveco, and the playing out of charm are not necessarily sexual harassment. [...]

I [only] regard it as sexism when male professors analyse [female] students' clothing in class, and comment on their appearance. 
Based on this, we reaffirm the importance of classifying forms of behaviour that transgress personal boundaries as sexual harassment, respecting individual perceptions and sensibilities when dealing with this issue, and recognising the power issues involved in gender relations. It is vital for women to have access to information on this issue, to be made aware of its systemic nature, and to be made aware of the fact that many forms of sexual harassment are not adequately recognised. Among inappropriate forms of behaviour in a professional environment, undesired sexual contact is the most serious. As reported in Table 7, significant levels of women respondents reported experiencing undesired physical or sexual contact, whether once, occasionally or often. When female teaching staff only are considered, $14 \%$ reported experiencing undesired sexual contact at least once, and one female teacher reported experiencing this frequently.

Table 7: Frequency of witnessing or experiencing sexual harassment

\begin{tabular}{|c|c|c|c|c|c|c|}
\hline \multirow{2}{*}{$\begin{array}{l}\text { Behaviour } \\
\text { Frequency }\end{array}$} & \multicolumn{2}{|c|}{$\begin{array}{c}\text { Inappropriate eye } \\
\text { contact or body language }\end{array}$} & \multicolumn{2}{|c|}{$\begin{array}{l}\text { Undesired physical } \\
\text { contact }\end{array}$} & \multicolumn{2}{|c|}{$\begin{array}{l}\text { Undesired sexual } \\
\text { contact }\end{array}$} \\
\hline & Female & Male & Female & Male & Female & Male \\
\hline Never experienced & $17 \%$ & $31 \%$ & $48 \%$ & $53 \%$ & $58 \%$ & $62 \%$ \\
\hline Only witnessed & $14 \%$ & $30 \%$ & $15 \%$ & $21 \%$ & $14 \%$ & $18 \%$ \\
\hline Experienced once & $11 \%$ & $3 \%$ & $13 \%$ & $6 \%$ & $13 \%$ & $6 \%$ \\
\hline $\begin{array}{l}\text { Experienced occa- } \\
\text { sionally }\end{array}$ & $17 \%$ & $10 \%$ & $4 \%$ & $1 \%$ & $3 \%$ & $1 \%$ \\
\hline Experienced often & $38 \%$ & $20 \%$ & $17 \%$ & $12 \%$ & $9 \%$ & $7 \%$ \\
\hline
\end{tabular}

Source: created by the authors.

The following statements confirm the role of individual perceptions of instances of sexual harassment, as well as their potential to detract from learning and cause emotional stress.

A teacher once flirted with me while I was a student, and a fellow student flirted with me as well. In both cases, I made it clear that I was not interested, and what could now be considered as harassment ended ...

I received compliments from the teacher about my physical appearance. This made me try not to be alone with him in the classroom for fear. It harmed my learning.

Most inappropriate conduct came from supposed colleagues and people in positions of authority (see Figure 19). 
Figure 19: People responsible for inappropriate behaviour

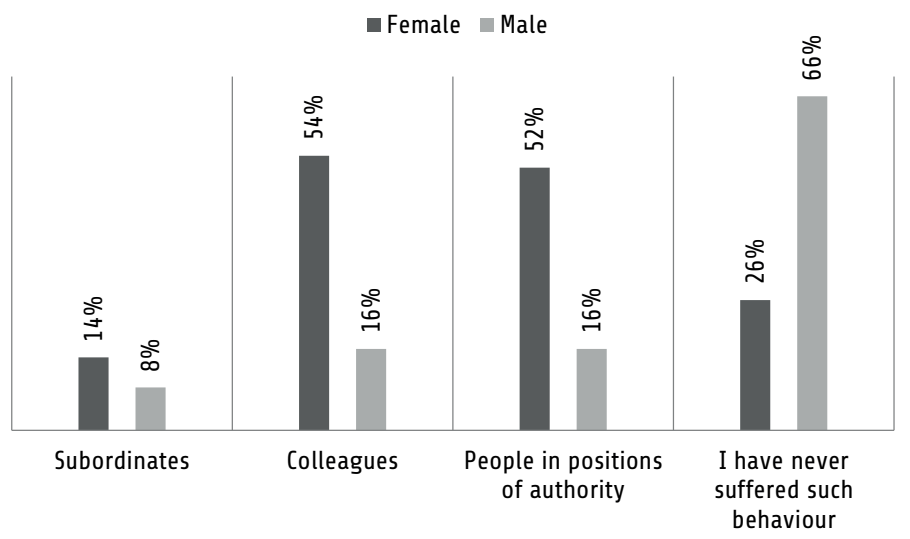

Source: created by the authors.

There are differences between how male and female respondents reported handling sexual harassment and other inappropriate behaviours. Considering only the answers of those who declared having suffered inappropriate conduct, nearly $51 \%$ of female respondents said that their response to the incidents in question was to ignore them. In contrast, $26 \%$ of male respondents followed suit. Most female respondents reported having talked to other colleagues about the incidents in question, and only one man initiated legal action. This conforms with the finding of Monroe et al (2008) that legal mechanisms are not employed because their potential benefits are unclear, whereas the costs are high and real.

Table 8: Responses to sexual harassment and other inappropriate behaviours by gender

\begin{tabular}{lcc}
\hline & Female & Male \\
\hline I ignored it & $51 \%$ & $26 \%$ \\
\hline $\begin{array}{l}\text { I told the offender of my displeasure } \\
\text { about his conduct }\end{array}$ & $29 \%$ & $26 \%$ \\
\hline I talked to other colleagues not involved & $60 \%$ & $48 \%$ \\
\hline $\begin{array}{l}\text { I talked to someone in a position of } \\
\text { authority }\end{array}$ & $17 \%$ & $16 \%$ \\
\hline I started legal action & & $1 \%$ \\
\hline
\end{tabular}

Source: created by the authors.

Some illustrative statements follow.

I avoided future contact.

I alerted other colleagues to the offender's misbehaviour, and identified the offender.

My colleagues were intimidated. I thought about taking legal action, but did not do so. 
I denounced [the offender] to the university's feminist collectives.

A final question dealt with the environment of women in the workplace. Only 19\% of respondents said that active steps had been taken to improve the status of females in their departments, which signals that Brazilian IR academia still needs to do a lot more in this regard.

Figure 20: Environment for women in the workplace

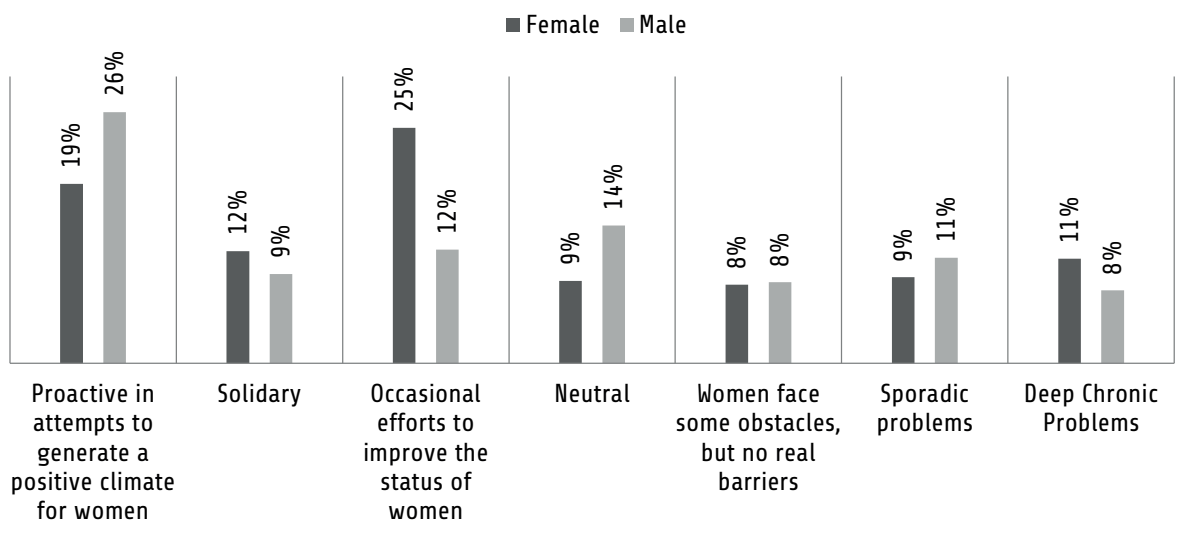

Source: created by the authors.

\section{Concluding remarks}

In 1965, Alice Rossi first pointed to the low levels of participation of women and the predominance of men in North American academia. Continued gender discrimination shows that despite being centres of knowledge promotion, academic institutions do not value diversity, and their 'environments are not healthy for individuals, for departments, for our students, or for the production of knowledge' (Pike 2018).

In this article, we have sought to analyse the conditions experienced by female members of IR faculties in Brazil, based on a 2017 survey as well as a report about IR departments at public and private universities. The data shows that the careers of women academics are still unequal in financial or familial terms as well as professional opportunities. More seriously, it shows that women in Brazilian IR still experience gender discrimination and sexual harassment - some $73 \%$ of female respondents reported being subjected to sexist jokes and language, $68 \%$ reported not being taken seriously because of their gender and $50 \%$ that their professional activities had been devalued because of their gender. Even more seriously, one third of female respondents reported that they had experienced undesired physical contact, a quarter reported that they had suffered undesired sexual contact, and a gap emerged between male and female perceptions of what constitutes sexual harassment. 
IR academia should address these challenges urgently and actively. Sexual harassment can amount to institutional betrayal, which is particularly relevant since, in Brazil, academia represents one of few paths to financial independence for many women. Given the problems surrounding legal action as a means of combating gender discrimination and sexual harassment, we support Pike's (2018) idea of establishing 'Hush Harbours', where victims could talk about their experiences in safety, and receive various forms of support. We also reinforce the importance of fighting retaliation against whistle-blowers in cases of discrimination and harassment.

While gender studies have developed over decades, discrimination, sexism and harassment will not end because they have been identified by researchers and gender research groups. Therefore, researchers should continue to identify dynamics of gender differentiation, and better-informed academics should help to end them and to promote diversity in academic institutions.

To conclude, we recognise that, due to the project design, some important variables such as sexuality, race and generational issues have not been addressed. Future studies should seek to understand the impact of gender and race on gender discrimination and sexual harassment, and map out where and when harassment and discrimination take place. Knowing that at points in their careers women academics experience discrimination and harassment, and knowing whether the stalkers are taking advantage of institutional positions of power, are essential for addressing this problem.

\section{Notes}

1 ABRI is a scientific association for the promotion of IR as a field of study. Founded in 2005, it draws together professors, researchers, students and professionals, providing spaces for dialogue between those involved in different thematic areas. Its aims are to stimulate and disseminate academic-scientific production, and encourage debate, teaching, researching and professional practice. It also represents the Brazilian IR community in various ways, both nationally and internationally.

2 We thank MulheRIs for promoting the development of the survey, and ABRI for its support and providing information for the survey and the research report.

3 The core proposal of feminist epistemology is that knowledge can be influenced by the contexts in which it is produced and therefore is marked by the scientists' non-cognitive values (Anderson 2017). To think about the world through a field's perspective involves accepting certain limits intrinsic to the practices that constitute the field, such as which themes are considered relevant, what types of experiences are reliable and what conceptual and theoretical frameworks are most useful. The omission of gender issues may generate systematic distortions, at the expense of conceptual clarity, empirical acceptability and explanatory power (Smith 1974).

4 Brazilian HEIs are heterogenous, being $8.2 \%$ public and the rest private. Most of the former are universities that undertake research as well as undergraduate and graduate education, while most of the latter are schools or colleges focusing on undergraduate teaching (Schwartzman and Balbachevsky 1993). Average lecturers in public institutions are male, aged 34 , have PhDs and work full time, while those in private institutions are male, aged 36, have master's degrees, and work part-time.

5 Since this research focuses on universities, we do not delve into the issue of domestic work. However, we recognise its importance and the need for further research linking it to the academic setting.

6 Increasing the number of women in stable and high-ranking positions in institutions by $1 \%$ would reduce the annual salary gap at the analysed universities of the USA by $\$ 2825.16$. An increase in the number of female teachers and teaching assistants (more unstable and lower positions) would not affect the salary gap 
and, contrary to expectations, having women in the highest university positions (rectors and presidents) would actually increase it (Lee and Won 2014).

$7 \quad$ Maliniak et al 2013 and Mitchell et al 2013 analyse the case of IR articles.

8 Meyers (2013) claims that the neoliberal ideology which emphasises productivity-oriented dynamics and focuses on individual responsibility in contemporary academia contributes to persistent gender discrimination and allows for post-feminist views that gender equality has already been achieved, thereby making feminism obsolete. According to Gill and Scharff (2013), the post-feminists are self-regulating women who constantly discipline themselves, but present this as freely chosen conduct.

9 The survey developed by CSW/WCIS is global in scope as it focuses on the International Studies Association (ISA). ISA has more than 7000 members in 80 countries. While most of them are in North America, Western Europe, Australia and Japan, and fewer in African countries (ISA 2018), it offers a broad representation of IR academics.

10 In Brazil, not all IR undergraduate courses are institutionally allocated under IR departments. Therefore, the reasoning was to collect information about teachers who were allocated to IR undergraduate courses.

11 The email read: 'REQUEST FOR COLLABORATION IN RESEARCH. Dear [male and female] associates: We ask for your contribution by answering a Survey about the academic community of International Relations in Brazil focusing on gender relations. The questionnaire is available at https://en.surveymonkey. com/r/MulheRIs.' We used the term 'associate' in both male and female forms, which are different in Portuguese, the language in which the invitation was written.

12 Given the population 1118 ABRI members, we need 287 respondents for a 95\% level of confidence in the answers, with a 5\% margin of error (Paranhos et al 2013).

13 Even though the survey was sent to both male and female ABRI members, some men wrote back to ask whether or not they should respond. This provides a lesson for future work.

14 The first category, 'full member' (sócio-pleno), includes faculty members and researchers of stricto sensu graduate and undergraduate programmes in IR. The second group, 'student member' (sócio-estudante) encompasses $\mathrm{PhD}$ candidates as well as masters and undergraduate students. 'Professional members' (sócio-profissional) refers to individuals with known expertise who are professionally active in IR.

15 In order to control for other variables that could explain this gap, we ran an ordered logistic regression (ologit) for two different samples: one comprising all academics, and another comprising only teachers at private institutions. Our model considered levels of income as the dependent variable, as well as four independent variables: gender, type of institution (whether public or private), number of disciplines taught and career length. In the first case, we identified lower salaries for women working at private institutions, as well as less time in their careers (this last one with significant results). In the second case, women again appeared to earn less than men, due to the number of disciplines taught (although this effect was minor). Above all, career time remained the most important factor explaining different levels of pay.

16 The chi-square test is a non-parametric technique of data analysis. It compares the frequency observed with the expected values. The higher the chi-square value, the greater the association between the variables.

\section{References}

Anderson, E. 2015. 'Feminist epistemology and Philosophy of Science.' In E N Zalta (ed), The Stanford Encyclopedia of Philosophy. At https://plato.stanford.edu/archives/spr2017/entries/feminism-epistemology/ [Accessed on 3 May 2018].

Balbachevsky, E and D Holzhacker. 2015. 'The academic profession in Brazil.' International Higher Education. At https://ejournals.bc.edu/ojs/index.php/ihe/article/download/7408/6605 [Accessed on 19 August 2018].

Benson, K. 1984. 'Comments on Crocker's "An analysis of university definitions of sexual harassment."' Signs 6: 516-519. 
Berdahl, J L. 2007. 'The sexual harassment of uppity women.' Journal of Applied Psychology 92 (2): 425-437.

Biroli, F. 2016. 'Divisão Sexual do Trabalho e Democracia.' DADOS - Revista de Ciências Sociais 59 (3): 719-681.

_ 2015. 'Responsabilidades, cuidado e democracia.' Revista Brasileira de Ciência Política 18: 81-117.

. 2010. 'Gênero e família em uma sociedade justa: Adesão e crítica à imparcialidade no debate Contemporâneo sobre justiça.' Revista de Sociologia e Política 18 (36): 51-65.

Briton, D. 2017. 'The salience of gender in women's academic careers.' Gender \& Society 31 (1): 5-27.

Colgan, J. 2017. 'Gender bias in International Relations graduate education? New evidence from syllabi.' Political Science \& Politics 50 (2): 456-460.

Conselho Nacional de Desenvolvimento Científico e Tecnológico - CNPq [Brazil]. 2013. Número de mulheres cientistas já iguala o de homens. Brasilia. At http://www.cnpq.br/web/guest/noticiasviews/-/journal_content/56_INSTANCE_a6MO/10157/905361 [Accessed on 3 May 2018].

Crasnow, S, A Wylie, W K Bauchspies and E Potter. 2015. 'Feminist perspectives on acience.' In E N Zalta (ed), The Stanford Encyclopedia of Philosophy. At https://plato.stanford.edu/archives/spr2018/ entries/feminist-science/ [Accessed on 19 August 2018].

Dresden, B E, A Y Dresden, R D Ridge and N Yamawaki. 2017. 'No girls allowed: Women in male-dominated majors experience increased gender harassment and bias.' Psychological Reports 0 (0): 1-16.

Dubois-Shaik, F and B Fusulier. 2017. 'Understanding gender inequality and the role of the work/ family interface in contemporary academia: An introduction. European Educational Research Journal 16 (2-3): 99-105.

Ellis, S and A Pinto. 1991 'Moderating effects of personal cognitions on experienced and perceived sexual harassment of women at the workplace.' Journal of Applied Psychology 21: 1320-1337.

Elsevier. 2017. Gender in the Global Research Landscape. Rio de Janeiro. At https://www.elsevier. com/_data/assets/pdf_file/0008/265661/ElsevierGenderReport_final_for-web.pdf [Accessed on 3 May 2018].

Fitzgerald, L F and A J Ormerod. 1991. 'Perceptions of sexual harassment: The influence of gender and academic context.' Psychology of Women Quarterly 15: 281-294.

Fitzgerald, L F, S L Shullman, N Bailey, M Richards, J Swecker, Y Gold, M Ormerod and L Weitzman. 1988. 'The incidence and dimensions of sexual harassment in academia and the workplace.' Journal of Vocational Behavior 32: 152-175.

Fukuda, R F. 2012. 'Assédio Sexual: Uma releitura a partir das relações de gênero.' Simbiótica 1 (1): 1-17.

Gill, R and C Scharff. 2013. New femininities: Postfeminism, Neoliberalism and Subjectivity. New York: Palgrave Macmillan.

Grossi, M G R, S D B Borja, A M Lopes and A M L Andalecio. 2016. 'As mulheres praticando ciência no Brasil.' Estudos Feministas 24 (1): 11-30.

Gruber, J E and S Fineran. 2007. 'The impact of bullying and sexual harassment on middle and high school girls.' Violence against Women 13 (6): 627-643. 
Hall, R M and B R Sandler. 1982. The Classroom Climate: A Chilly One for Women? At http://eric. ed.gov/PDFS/ED215628.pdf [Accessed on 3 May 2018].

Hancock, K, M Baum and M Breuning. 2013. 'Women and pre-tenure scholarly productivity in international studies: an investigation into the leaky career pipeline.' International Studies Perspectives 14 (4): 507-527.

Haraway, D. 2006. 'When we have never been human, what is to be done?: Interview with Donna Haraway.' Theory, Culture \& Society 23 (7-8): 135-158.

Harding, S. 2016. 'Sandra Harding: On Standpoint Theory's History and Controversial Reception.' Villa Nova University YouTube channel [online], 4 May. At https://www.youtube.com/ watch? $\mathrm{v}=\mathrm{xOAMc12PqmI} \& \mathrm{t}=24 \mathrm{~s}$ [Accessed on 3 May 2018].

Higa, F da. 2016. 'Assédio sexual no trabalho e discriminação de gênero: duas faces da mesma moeda?' Revista Direito GV 12 (2): 484-515.

Hudson, V M, N Haight and C Fattore. 2016. 'The 2015 ISA CSW/WCIS Survey on Women in the Profession of International Studies: A Preliminary Analysis.' Paper delivered at the International Studies Association annual conference, Atlanta, USA, 16-19 March.

Instituto Nacional de Estudos e Pesquisas Educacionais Anísio Teixeira (INEP). 2017. Censo da Educação Superior 2016. Brasília. At http://download.inep.gov.br/educacao_superior/censo_superior/ documentos/2016/censo_superior_tabelas.pdf [Accessed on 19 August 2018].

International Studies Association (ISA). 2018. Data on ISA's Scope and Membership. At https:// www.isanet.org/ISA/About-ISA/Data [Accessed on 19 August 2018].

Lee, Y-j and D Won. 2014. 'Trailblazing women in academia: Representation of women in senior faculty and the gender gap in junior faculty's salaries in higher educational institutions.' The Social Science Journal 51: 331-340.

Leskinen, E A, L M Cortina and D B Kabat. 2011. 'Gender harassment: Broadening our understanding of sex-based harassment at work.' Law and Human Behavior 35: 25-39.

Leta, J. 2003. 'As mulheres na ciência brasileira: crescimento, contrastes e um perfil de sucesso.' Estudos Avançados 48 (17): 271-284.

MacKinnon, C. 1979. Sexual Harassment of Working Women: A Case of Sex Discrimination. New Haven: Yale University Press.

MacNell, L, A Driscoll and A N Hunt. 2014. 'What's in a name: exposing gender bias in student ratings of teaching.' Innovative Higher Education 40 (4): 291-303.

Magley, V J and E I Shupe. 2005. 'Self-labeling sexual harassment.' Sex Roles 53: 173-189.

Magley, V J, C Hulin, L Fitzgerald and M DeNardo. 1999. 'Outcomes of self-labeling sexual harassment.' Journal of Applied Psychology 84: 390-402.

Maliniak, D, R Powers and B Walter. 2013. 'The gender citation gap in International Relations.' International Organization 67 (4): 889-922.

McLaughlin, H, C Uggen and A Blackstone 012. 'Sexual harassment, workplace authority, and the paradox of power.' American Sociological Review 77 (4): 625-647.

Mendes, M V I and A R Figueira. 2017. 'Participação da Mulher no Ensino e Pesquisa em Ciência Política e Relações Internacionais no Brasil.' Paper delivered at $6^{\circ}$ Encontro da Associação Brasileira de Relações Internacionais (ABRI): Perspectivas sobre o poder em um mundo em redefinição. Belo Horizonte, Brazil, 25-28 July. 
Meyers, M. 2013. 'The war on academic women: reflections on postfeminism in the neoliberal Academy'. Journal of Communication Inquiry 37 (4): 274-283.

Mitchell, S M, S Lange and H Brus. 2013. 'Gendered citation patterns in International Relations journals.' International Studies Perspectives 14: 485-492

Mohipp, C and C Y Senn. 2008. 'Graduate students' perceptions of contrapower sexual harassment.' Journal of Interpersonal Violence 23 (9): 1258-1276.

Monroe, Kristen, S Ozyurt, T Wrigley and A Alexander. 2008. 'Gender equality in academia: bad news from the trenches, and some possible solutions. Perspectives on Politics 6 (2): 215-233.

Moschkovich, M and A F Almeida. 2015. 'Desigualdades de Gênero na Carreira Acadêmica no Brasil.' Dados - Revista de Ciências Sociais 58 (3): 749-789.

O'Laughlin, E M and L G Bischoff. 2005. 'Balancing parenthood and academia: Work/family stress as influenced by gender and tenure status.' Journal of Family Issues 26 (1): 79-106.

Paranhos, R, Dalson Britto Figueiredo Filho, Enivaldo Carvalho da Rocha and José Alexandre da Silva Junior. 2013. Corra que o survey vem aí: noções básicas para cientistas sociais. Revista Latinoamericana de Metodología de la Investigación Social 3 (6): 7-24.

Prentice, S. 2000. 'The conceptual politics of chilly climate controversies.' Gender and Education 12 (2): 195-207.

Pike, K D. 2018. 'Institutional betrayal: inequity, discrimination, bullying, and retaliation in academia.' Sociological Perspectives 61 (1): 5-13.

Rivera, L A. 2017. 'When two bodies are (not) a problem: gender and relationship status discrimination in academic hiring.' American Sociological Review 82 (6): 1111-1138.

Robinson, K. 2005. 'Reinforcing hegemonic masculinities through sexual harassment: issues of identity, power and popularity in secondary schools.' Gender and Education 17 (1): 19-37.

Rossi, A. 1965. 'Women in science: why so few?' Science 148 (3674): 1196-1202.

Schwartzman, S and E Balbachevsky. 1993. 'The academic profession in Brazil.' Working Paper 1/93 Núcleo de Pesquisas sobre Ensino Superior.

Smith, D. 1974. 'Women's perspective as a radical critique of sociology'. Sociological Inquiry 44 (1): 7-13.

Tunguz, S. 2016. 'In the eye of the beholder: emotional labor in academia varies with tenure and gender.' Studies in Higher Education 41 (1): 3-20.

Uggen, C and A Blackstone. 2004. 'Sexual harassment as a gendered expression of power' American Sociological Review 69 (1): 64-92.

Van den Brink, M and Y Benschop. 2012. 'Slaying the seven-headed dragon: the quest for gender change in academia.' Gender, Work and Organization 19 (1): 71-92.

Velho, L and E León. 1998. 'A construção social da produção científica por mulheres.' Cadernos Pagu 10: 309-344.

Wolfe, D A and D Chiodo. 2008. 'Sexual harassment and related behaviors reported among youth from Grade 9 to Grade 11. Toronto: Centre for Addiction and Mental Health. At http://citeseerx.ist.psu. edu/viewdoc/download?doi=10.1.1.586.6071\&rep=rep1\&type=pdf [Accessed on 23 February 2019].

Yee, M T W, P N Alagappar and Y M Ngeow. 2015. 'Differences in the perception of sexual harassment by gender and ethnicity among selected Malaysian undergraduates.' Gender, Technology and Development 19 (2): 204-230. 


\section{About the authors}

Mariana Pimenta Oliveira Baccarini is an Adjunct Professor of International Relations at the Federal University of Paraíba. She holds a Ph.D. in Political Science from the Federal University of Minas Gerais (2014) and an MA in International Relations from the Pontifical Cathlic University of Minas Gerais (2010). She focuses on Political Science, with an emphasis on International Politics. Her current research topics include institutional theory, institutional change, international institutions and the UN Security Council.

Xaman Korai Minillo is an Adjunct Professor of International Relations at the Federal University of Paraíba and a Ph.D. Candidate at the University of Bristol. She holds an MA (2011) and BA (2008) in International Relations from University of Brasília. Current research interests include African sexualities and state homophobia in Zimbabwe.

Elia Elisa Cia Alves is an Adjunct Professor in the Political Science Department of the Federal University of Pernambuco (UFPE). She holds a Ph.D. in Political Science from UFPE (2017) and an MA in Economics from Unicamp (2012). Current research interests include energy politics, political economy and environmental politics. 


\section{Questões de Gênero na Torre do Marfim de RI no Brasil}

Resumo: Qual é o status das mulheres na Academia Brasileira de Relações Internacionais? Essa pesquisa traça um mapa sem precedentes de questões de gênero enfrentadas por pesquisadores brasileiros de relações internacionais com foco em questões de desigualdade, discriminação e assédio. O artigo oferece uma revisão da literature sobre o tema e os resultados obtidos através de dois conjuntos de dados auto-compilados. O primeiro foi consolidado a partir de uma pesquisa aplicada entre Junho e Julho de 2017 com foco em questões pessoais e profissionais enfrentadas por acadêmicos brasileiros de estudos internacionais e o segundo foi compilado mapeando a composição do corpo docente em RI e departamentos relacionados no Brasil. Nossas descobertas indicam que, apesar das espeficidades do sistema de ensino superior brasileiro, acadêmicos brasileiros de RI seguem as tendências internacionais, enfrentando as desigualdades monetárias e/ou familiares e discriminação de gênero em suas carreiras. Os resultados também mostram que 25\% das mulheres enfrentaram contato sexual indesejado pelo menos uma vez, e que existe uma lacuna entre entendimentos de homens e mulheres sobre o que constitui assédio sexual.

Palavras-chave: desigualdade de gênero; discriminação de gênero; assédio sexual; Academia Brasileira de Relações Internacionais; MulheRIs; análise empíricas; estudos de gênero.

Received on 7 May 2018, and approved for publication on 18 December 2018. 